\title{
Stainless steel corrosion in instrumentation pipe
}

\section{Corrosão do aço inoxidável em tubing de instrumentação}

\author{
1 Jean Victal do Nascimento \\ 1 Rafael Adão de Carvalho \\ 1 Davi Pereira Garcia davi.garcia@ifes.edu.br \\ 2 Rômulo Maziero \\ 2 Edelize Angelica Gomes \\ 2 Juan Carlos Campos Rubio
}

1 Federal Institute of Education, Science and Technology of Espirito Santo - IFES

2 Post-Graduate Program in Mechanical Engineering - PPGMEC of the Federal University of Minas Gerais - UFMG

\begin{abstract}
Corrosion, being a destructive process, causes damage in almost all industrial sectors. In this way, it is harmful both from an economic, social and, especially, safety point of view, as it can cause failures in critical equipment and components of an industrial process. At this point, stainless steels are considered the most corrosion resistant metals. The resistance depends on the chemical composition and microstructure, factors that directly influence the passivation of these materials. The resistance is proportionally related to the addition of chromium $(\mathrm{Cr})$ to the mixture, as well as other alloying elements, among which is the molybdenum (Mo), whose main function is to maximize corrosion resistance in the marine atmosphere, as in case of austenitic stainless steel AISI 316, which presents in the chemical composition a percentage of the element Mo. Austenitic stainless steels are applied in instrumentation systems in tubing for reliability in severe atmospheres in accordance with ASTM A269, which establishes the materials applicable to this function. Thus, the present work presents, through a review and case study, Pitting Corrosion of tubings of austenitic stainless steel AISI 316 in the presence of chloride ions $(\mathrm{Cl})$ coming from the marine atmosphere. The results show that there is no change in the longitudinal and transverse structure for all analyzed tubes, showing a homogeneous austenitic structure, free of intergranular precipitations.
\end{abstract}

\section{Keywords:}

Steel AISI 316. Molybdenum. Pitting corrosion.

\section{Resumo}

A corrosão, por ser um processo destrutivo, causa danos em quase todos os setores industriais. Desta forma, é prejudicial tanto do ponto de vista econômico, social e, principalmente, de segurança, pois pode causar falhas em equipamentos críticos e componentes de um processo industrial. Neste ponto, os aços inoxidáveis são considerados os metais mais resistentes à corrosão. A resistência depende basicamente da composição química e da microestrutura, fatores que influenciam diretamente na passivação desses materiais. A resistência está proporcionalmente relacionada à adição de cromo (Cr) à mistura, assim como outros elementos de liga, dentre os quais o molibdênio (Mo), cuja função principal é maximizar a resistência à corrosão na atmosfera marinha, como no caso de aço inoxidável austenítico AISI 316, que apresenta na composição química uma porcentagem do elemento Mo. Os aços inoxidáveis austeníticos são aplicados em sistemas de instrumentação em tubulações, para confiabilidade em ambientes severos, de acordo com a norma ASTM A269, que estabelece os materiais aplicáveis a esta função. Assim, o presente trabalho apresenta, por meio de uma revisão e estudo de caso, corrosão por pite de tubulações de aço inoxidável austenítico AISI 316 na presença de íons cloreto $(\mathrm{Cl})$ provenientes da atmosfera marinha. Os resultados mostram que não há alteração na estrutura longitudinal e transversal de todos os tubos analisados, mostrando uma estrutura austenítica homogênea, livre de precipitações intergranulares.

\section{Palavras-chave:}

Aço AISI 316. Molibdênio. Corrosão por pite.

\section{Como você deve citar?}

NASCIMENTO, Jean Victal do et al. Stainless steel corrosion in instrumentation pipe. Cadernos UniFOA, Volta Redonda, n. 40, p. 31-40, agosto 2019. 


\section{INTRODUCTION}

Corrosion problems are frequent and occur in the most varied activities, causing significant economic losses (GENTIL, 2011). According to Roberge (1999), the economic cost of corrosion in metals generates for the economy of the United States something around 300 billion dollars per year. Application of corrosion resistant materials and application of best practices can reduce approximately $1 / 3$ of this cost.

The classification of these economic losses can best be exemplified, according to Gentil (2011), as a function of corrosion, direct and indirect. The direct losses from corrosion come from the costs related to the replacement of the parts or equipment that suffered corrosion, as well as the labor and energy employed. Costs with the maintenance of the protection processes (cathodic protection, coatings, and paintings, among others) also enter losses. Regarding indirect losses, there are phenomena such as accidental shutdowns, loss of efficiency of certain equipment, contamination of products, oversizing of projects, among others. In this respect, the total cost of the losses due to corrosion in $4 \%$ of the gross national product is evaluated (GEMELLI, 2014). Therefore, it is necessary to study the implementation of the project for the best way to mitigate corrosion, avoiding the prior stop of equipment for inspection or maintenance.

Despite the search for new materials with different properties for different applications, steel is the most important and most employable material, being used in many applications due to availability, cost of ownership and mechanical properties (SILVA; MEI, 2013).

However, there are steels with high resistance to corrosion, such as stainless steels. Yet, although the corrosion resistance of stainless steels is high $(<0.005 \mathrm{~mm} /$ year for steels with more than $2.5 \%$ chromium, $\mathrm{Cr}$, in composition), it does not mean that they are completely resistant to corrosive process, for example, pitting corrosion on media where the passive film is ruptured or there is a deficiency in the formation. The stability of the passive film depends heavily on the alloying elements present in the steel. The main one is molybdenum (Mo), which has a direct correlation with the greater homogeneity of the film (CHIAVERINI, 1986; TELLES, 2003; GUO et al., 2018).

In this context, it is necessary to study the scientific aspects related to the characteristics of the passive film and the mechanisms of corrosion. Likewise, from the technological point of view, that is, in the use of these materials in service, it is also necessary to establish the aggressive conditions of limits in which they can be used. The objective of this work was to evaluate the origin of the corrosion failure in the stainless steel tubings installed in the process plant and to analyze the possibilities regarding the mitigation of corrosion in the components.

\section{MATERIALS AND METHODS}

Failure analysis was performed on failed pipeline samples from offshore oil platform exposure located $120 \mathrm{~km}$ offshore of Brazil, as well as samples of flawless tubings that had been operating for more than a decade in conditions and tubing samples stored in stock.

To support the analysis, in addition to the visual test, TECMETAL analyzes were performed by Scanning Electron Microscopy (SEM), chemical analyzes by Optical Emission Spectroscopy (OES), hardness measurements, metallographic analyzes by Optical Microscopy (OM) and microanalysis by Dispersive Energy Spectroscopy (EDS). For better correlation of results and identification of samples, as reported in Table 1. 
Table 1 - Identification of samples.

\begin{tabular}{cc}
\hline Identification & Sample \\
\hline TE & Tubing in stock. \\
TF & Tubing in a failed operation. \\
TO & Tubing in operation without failure. \\
\hline
\end{tabular}

Source: authors, 2019

Initially, a visual test of the samples that had failed in operation was performed according to the NBR 315 (2007) standard. In this way, it was necessary to prepare the samples for analysis by a company specializing in specific tests, TECMETAL.

The representation of tests for pitting analysis based on specific procedures and standardization is presented by the system established in ASTM G46 (2013). A metallographic test was carried out for measuring the depth of the pits. The preparation of the test specimens for corrosion analysis was performed by cutting the material perpendicular to the largest pitting, according to ASTM G46 (2013). The characterization of the tubes was based on the results of the chemical analysis performed by OES after conventional metallographic preparation and electrolytic attack based on oxalic acid, according to ASTM A269 (2013), practice A.

The hardness analysis was performed by the Vickers HV- 5 method (with an approximate test strength of $5 \mathrm{kgf}$ ) and was performed according to norm NBR NM 171 (2000). The performance of this procedure is important to verify that the hardness is within the specified for the material and to analyze if there was no formation of intermetallic compounds. To determine the influence of the medium regarding the cause of the failure, a chemical analysis of the surface deposits was carried out using OES, according to ASTM E1508 (2013). In this way, the purpose of the tests is to identify the fault, quantify the failure, identify the material, evaluate the mechanism of damage and the influence of the medium. Subsequently, the results of the tests were compared to the theoretical reference for a better conclusion of the cause of the failure, making it possible to issue recommendations for control to mitigate the failure.

\section{RESULTS AND DISCUSSION}

\subsection{Visual test}

The visual evaluation of the TF samples allowed to identify the presence of localized pitting corrosion associated to loss of significant material, according to Figure 1. 
Figure 1 - Predominance Pitting Corrosion in the Tubings.
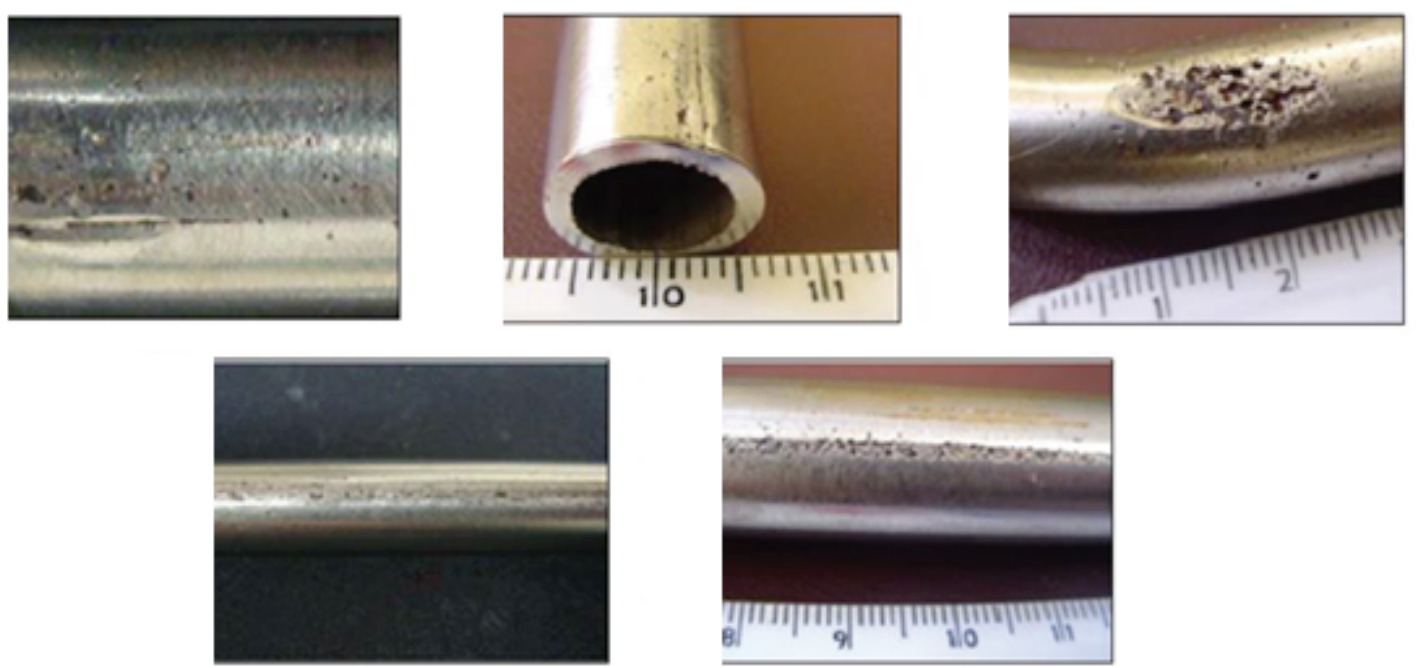

Source: TECMETAL, 2004.

Figure 1 shows the most critical points in which the material has suffered corrosion and is important for identifying the type of corrosion presented, in this case pitting. According to Telles (2003) and LI et al. (2018), this type of corrosion occurs due to rupture of the passive film and propagation of pitting when in the presence of halogen ions.

\subsection{Metallographic test}

The pitting morphology was defined by the microscopic and metallographic analysis of the cross-section to the tubing wall, according to ASTM G46 (2013). Figure 2 shows the microscopic appearance of pitting corrosion.

Figure 2 - Microscopic appearance evidencing pitting on the external surface.

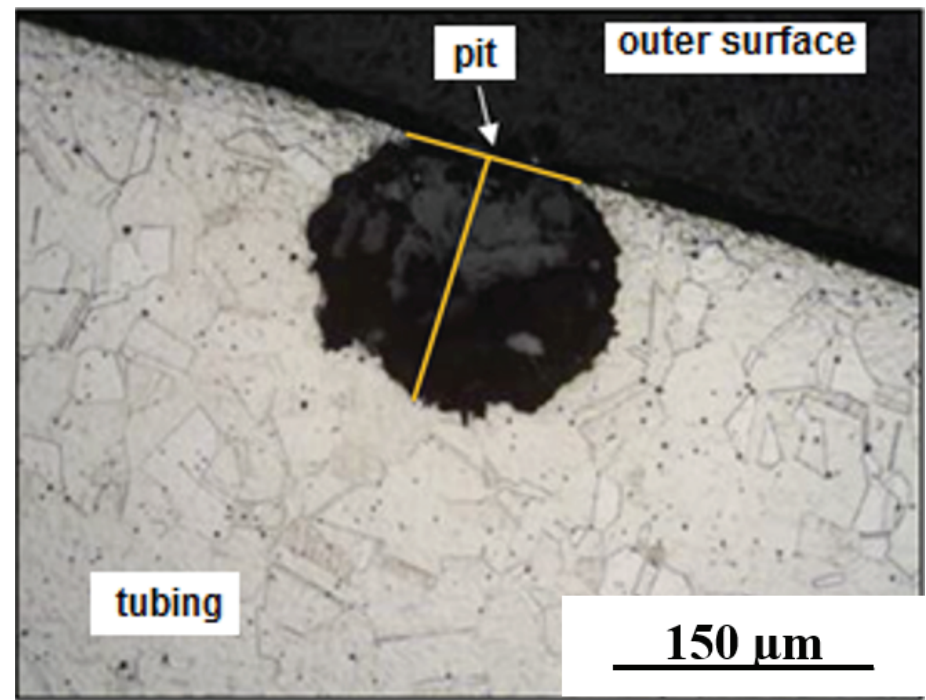

Source: adapted from TECMETAL, 2004.

Figure 2 shows the identification of the pitting according to ASTM G46 (2013), which shows a greater depth of penetration in the metal in relation to the penetration surface. The morphological 
analysis allows inferring that it is a pitting of the subsurface type since it did not reach the internal region of the tubing.

\subsection{Characterization}

The characterization of the material was carried out by chemical analysis by OES, hardness and OM measurements.

\subsubsection{Optical emission spectroscopy}

Table 2 presents the results of OES analysis in the samples TF, TE and TO, as well as a comparison with the constant chemistry in ASTM A269 (2013).

Table 2 - Comparison of chemical composition (\% weight).

\begin{tabular}{|c|c|c|c|c|c|c|c|c|c|}
\hline Material & C & Mn & $\mathbf{P}$ & $S$ & Si & $\mathrm{Cr}$ & $\mathrm{Ni}$ & Mo & $\mathrm{Nb}$ \\
\hline TF & 0.040 & 0.93 & 0.042 & 0.007 & 0.46 & 16.22 & 10.90 & 1.89 & 0.02 \\
\hline TE & 0.047 & 1.41 & 0.034 & 0.003 & 0.60 & 15.82 & 12.53 & 2.08 & 0.02 \\
\hline TO & 0.019 & 1.56 & 0.039 & 0.009 & 0.42 & 16.86 & 12.49 & 2.53 & 0.03 \\
\hline $\begin{array}{l}\text { AISI } 316 \text { (ASTM } \\
\text { A269) }\end{array}$ & $\begin{array}{l}0.080 \\
\max .\end{array}$ & $\begin{array}{l}2.00 \\
\max .\end{array}$ & $\begin{array}{l}0.045 \\
\max .\end{array}$ & $\begin{array}{l}0.030 \\
\max .\end{array}$ & $\begin{array}{l}1.00 \\
\max .\end{array}$ & $\begin{array}{l}16.00 \mathrm{a} \\
18.00\end{array}$ & $\begin{array}{l}10.00 \mathrm{a} \\
14.00\end{array}$ & $\begin{array}{l}2.00 \mathrm{a} \\
3.00\end{array}$ & - \\
\hline $\begin{array}{l}\text { AISI } 316 \text { L (ASTM } \\
\text { A269) }\end{array}$ & $\begin{array}{l}0.030 \\
\max \end{array}$ & $\begin{array}{l}2.00 \\
\max .\end{array}$ & $\begin{array}{l}0.045 \\
\max \end{array}$ & $\begin{array}{l}0.030 \\
\max .\end{array}$ & $\begin{array}{l}1.00 \\
\max .\end{array}$ & $\begin{array}{l}16.00 \mathrm{a} \\
18.00\end{array}$ & $\begin{array}{l}10.00 \mathrm{a} \\
14.00\end{array}$ & $\begin{array}{l}2.00 \mathrm{a} \\
3.00\end{array}$ & - \\
\hline
\end{tabular}

Source: authors, 2019 and ASTM A269, 2013.

The characterization shows that the tubings were made of austenitic stainless steel, whose chemical composition approximates the AISI 316 classification, and it was observed that the TF and TE samples were manufactured in AISI 316 austenitic stainless steel, while the TO sample was manufactured in stainless steel AISI $316 \mathrm{~L}$, since the percentage of carbon (C) is lower than $0.03 \%$.

In addition, it was verified that the Mo content of the TF sample is $1.89 \%$, being therefore below that specified for AISI 316 alloys. The TE sample presented Mo content close to $2 \%$ (within the normalized specification) and the TO sample with Mo content of $2.53 \%$.

In this way, it is observed that the value of the Pitting Resistance Equivalent Numbers (PREN) for the TF sample is below that established and required by the International Molybdenum Association (IMOA) for applications in marine atmosphere, while the value in the TO sample is above, according to Table 3. Figure 4 represents the sample collected in the corrosion products of the external surface analyzed by SEM, with subsequent microanalysis by EDS.

Table 3 - Comparison between PREN values.

\begin{tabular}{llll}
\hline Material & Cr & Mo & PREN \\
\hline TF & 16.22 & 1.89 & PREN $=16.22+3.3 * 1.89=22.457$ \\
TO & 16.86 & 2.53 & PREN $=16.86+3.3 * 2.53=25.179$ \\
\hline
\end{tabular}

Source: authors, 2019. 


\subsubsection{Hardness test}

To investigate the presence of intermetallic compounds, the hardness analysis of the TF samples was performed, as shown in Table 4.

Table 4 - Hardness Vickers - HV5 of samples that have failed.

\begin{tabular}{llll}
\hline Material & Hardness Vickers - HV5 & Average & Reference (ASTM A269) \\
\hline TF & $139-135-140-139$ & $138 \mathrm{HV}$ & $<200 \mathrm{HV}$ \\
\hline
\end{tabular}

Source: authors, 2019.

It is observed that the hardness of the material is in accordance with the standard ASTM A269 (2013), not being observed, together with the metallography, intergranular precipitations which, according to Monteiro and Lebrão (2015), would maximize the hardness, since the increase of the same occurs by the precipitation of phases of high hardness as the sigma phase, nitrites, and carbides.

\subsubsection{Optical microscopy}

Figure 3 shows the microstructural aspect of the TF sample after conventional metallographic preparation and electrolytic attack based on oxalic acid in cross section.

Figure 3 - Metallography of samples. .

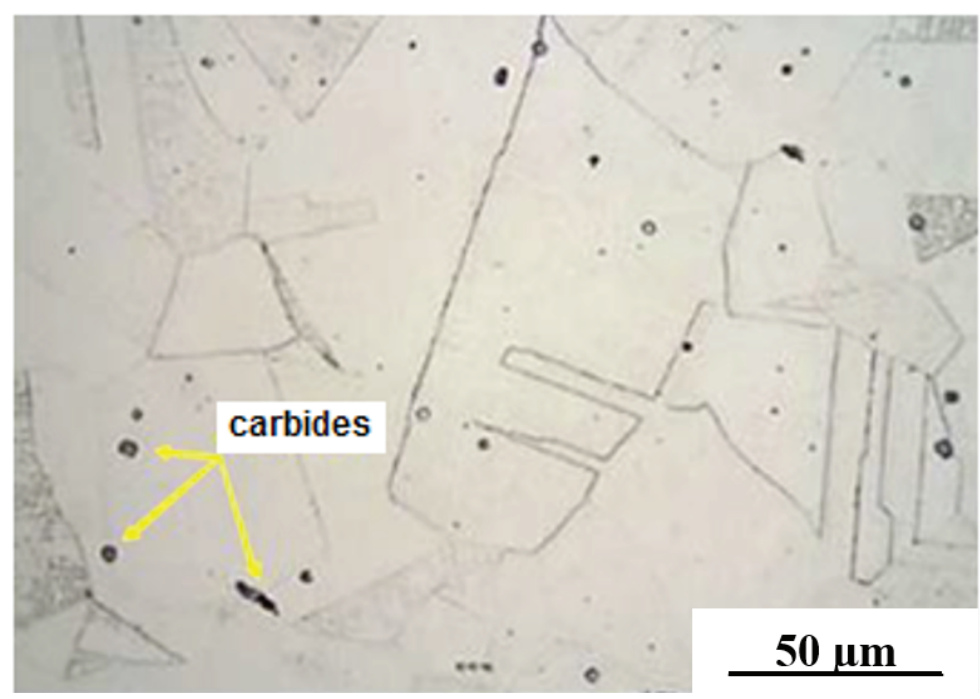

Source: TECMETAL, 2004

The results show that there is no change in the longitudinal and transverse structure for all analyzed tubes, showing a homogeneous austenitic structure, free of intergranular precipitations. Thus, the preferential sense of pitting occurrence was not motivated by any microstructural changes. It is possible to observe the formation of carbides of bulky and dark bodies dispersed in the austenitic matrix (arrows in yellow). These carbides are likely to result from the cooling process slowly.

Austenitic stainless steels may precipitate nitrides and carbides in the solid state at temperatures below $1100^{\circ} \mathrm{C}$ as the solubilities of nitrogen and $\mathrm{C}$ decrease appreciably below this temperature. On the other hand, below $500^{\circ} \mathrm{C}$ the precipitation of nitrides and carbides occurs very slowly (SOKEl et al., 2006). 
The precipitation of these elements did not occur in a severe way (sensitization), as there is no formation in the grain contours and no increase in hardness beyond the ASTM A269 (2013) standard is presented. It is also important to note that the percentage of $C$ is within the range specified by the standard. The formation of precipitates can establish the pitting phenomenon because, according to Martins and Lebrão (2012) and Grachev et al. (2017), the presence of precipitates is an indication for occurrence pitting corrosion, with pitting occurring in anodic areas on the steel surface.

\subsection{Surface chemical analysis}

Figure 4 represents the sample collected in the corrosion products of the external surface analyzed by MEV, with subsequent microanalysis by EDS.

Figure 4 - The sample for EDS analysis.

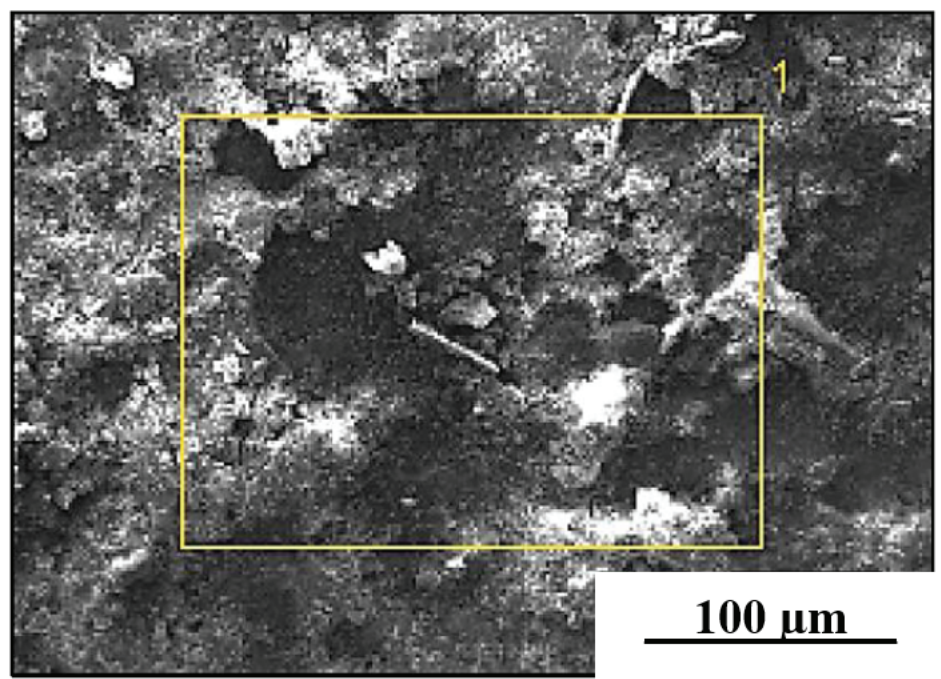

Source: TECMETAL, 2004

Figure 5 shows the presence of elements typically found in the marine atmosphere $(\mathrm{Cl}, \mathrm{Na}, \mathrm{K}, \mathrm{Ca}$ and $\mathrm{Mg}$ ), as well as $\mathrm{Si}, \mathrm{S}, \mathrm{Fe}, \mathrm{Al}, \mathrm{Zn}, \mathrm{Ba}, \mathrm{Cr}$ and $\mathrm{Ni}$ as peaks of the chlorine element, main responsible for the rupture of the passive protective film. 
Figure 5 - EDS analysis of the products collected on the surface of the tubing. .

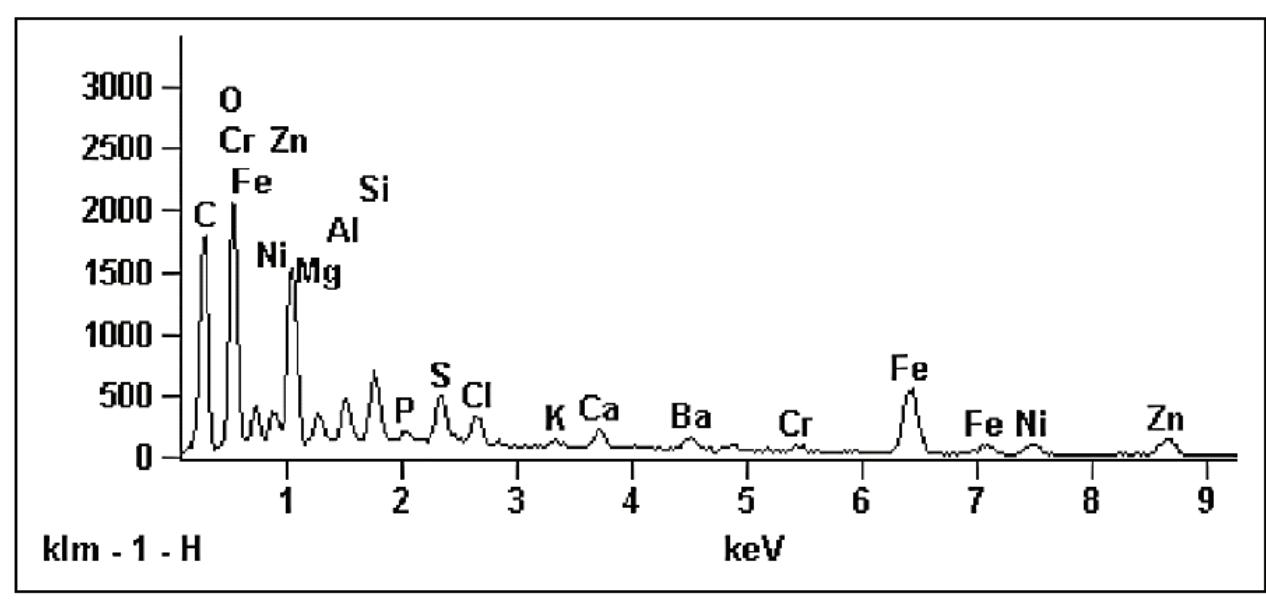

Source: TECMETAL, 2004

The phenomenon of the reaction of molybdenum with the atmosphere with chloride, $\mathrm{Cl}^{-}$, according to Pardo et al. (2008), has the effect on more than one factor in pitting prevention. First, Mo modifies the passive film by rendering it more stable against the break caused by the aggressive attack of $\mathrm{Cl}^{-}$ions. Then, during the dissolution of the MnS (manganese sulfide) and in the pitting stage, Mo can act by the formation of oxidized insoluble species, which cover the wall, allowing the process of repassivation and deactivation of pitting growth.

In this way, the molybdenum content has to meet the minimum required, due to the action of the atmosphere with chloride ions (changing the $\mathrm{pH}$ concentration) on the passive film as established by Staehle (2007), where the passive film varies in thickness depending on the time, temperature, potential, $\mathrm{pH}$ and in the species of the environment.

\section{CONCLUSIONS}

According to the results of the presented tests, the TF sample suffered pitting corrosion due to the action of the maritime atmosphere on the metallic surface, causing a breakdown of the passive layer. It contributed to the fact that the Mo content (1.89\%) was below that specified for AISI 316 alloys.

ASTM A269 (2013) standard establishes the chemical composition of AISI 316 the 2 to $3 \%$ Mo content and it is necessary to ensure that such components are supplied within the specification, especially considering that, among the alloying elements, molybdenum is the one which has the highest cost, which is why companies producing the raw material often supply such alloys with a lower threshold content, that is, close to the standard percentage of $2 \%$.

In addition, as a supplementary manufacturing and procurement requirement, the supplier may be required to guarantee that, in the manufacture of AISI 316, the tubing is shipped with a minimum Mo content of 2.5\%, as provided for in ASTM A269 (2013). Alternatively, for said applications, AISI 317 , whose Mo content is standardized at 3 to $4 \%$, which will provide for pitting corrosion resistance maximization, may replace the AISI 316 austenitic alloy. 


\section{$5 \quad$ ACKNOWLEDGMENTS}

The authors would like to thank the Federal Institute of Education, Science and Technology of Espírito Santo - IFES and the Post-Graduate Program in Mechanical Engineering - PPGMEC of the Federal University of Minas Gerais - UFMG, by the physical structure and support. The authors would like to thank the Brazilian Agencies CAPES, CNPq, and FAPEMIG for financial support.

\section{REFERENCES}

AMERICAN SOCIETY FOR TESTING AND MATERIALS. ASTM A269. Standard Specification for Seamless and Welded Austenitic Stainless Steel Tubing for General Service. Standard, West Conshohocken, 2013.

AMERICAN SOCIETY FOR TESTING AND MATERIALS. ASTM E1508. Standard Guide for Quantitative Analysis by Energy-Dispersive Spectroscopy. Standard, West Conshohocken, 2013.

AMERICAN SOCIETY FOR TESTING AND MATERIALS. ASTM G46. Standard Guide for Examination and Evaluation of Pitting Corrosion. Standard, West Conshohocken, 2013.

BRAZILIAN ASSOCIATION OF TECHNICAL STANDARDS. NBR 171. Steel Tubes - Hardness Test. Rio de Janeiro, 2000.

BRAZILIAN ASSOCIATION OF TECHNICAL STANDARDS. NBR 315. Non-Destructive Tests - Visual Test

- Procedure. Rio de Janeiro, 2007.

CHIAVERINI, V. Mechanical engineering materials. 2th. ed. São Paulo: Mcgraw-Hill, 1986.

GENTIL, V. Corrosion. 6th. ed. Rio de Janeiro: LTC, 2011.

GEMELLI, E. Corrosion of metallic materials and their characterization. 1th. ed. Rio de Janeiro: LTC, 2014.

GRACHEV, V.; NECHAEV, I.; ROZEN, A. E.; ROZEN, A. A. Mechanism of pitting corrosion protection of metals and alloys in new-generation water treatment plants. MATEC Web of Conferences, v. 132, n. 03013, p. 1-5, 2017.

GUO, P.; LA PLANTE, E. C.; WANG, B.; CHEN, X.; BALONIS, M.; BAUCHY, M.; SANT, G. Direct observation of pitting corrosion evolutions on carbon steel surfaces at the nano-to-micro- scales. Scientific Reports, v. 8, n. 7990, p. 1-12, 2018.

LI, Y.; HE, Y.; QIU, J.; ZHAO, J.; YE, Q.; ZHU, Y.; MAO, J. Enhancement of pitting corrosion resistance of austenitic stainless steel through deposition of amorphous/nanocrystalline oxy-nitrided phases by active screen plasma treatment. Materials Research, v. 21, n. 6, p. 1-10, 2018.

MARTINS, N. F.; LEBRÃO, S. M. G. Evaluation of Pitting Corrosion in Thermally Treated Uns S44400 Ferritic Stainless Steels and Analyzed in a Potentiodynamic Polarization Test. Mauá Engineering School, São Caetano do Sul, 2012.

MONTEIRO, F. T.; LEBRÃO, S. G. Metallographic and Hardness Evaluation of Thermally Treated Saf 2707 Hd Hyper Duplex Stainless Steel. Instituto Mauá, São Paulo, 2015. 
PARDO, A.; MERINO, M. C.; COY, A. E.; VIEJO, F.; ARRABAL, R.; MATYKINA, E. Pitting Corrosion Behavior of Austenitic Stainless Steels - Combining Effects of Mn and Mo Additions. Corrosion Science, v. 50, n. 6, p. 1796-1806, 2008.

ROBERGE, P. R. ASM handbook of corrosion engineering. Houston, Mcgraw-Hill, 1999.

SILVA, A. L. V. C.; MEI, P. R. Special steels, and alloys. 3th. ed. São Paulo: Blucher, 2013.

SOKEI, C. R.; FERREIRA, I.; TOKIMATSU, R. C.; VENTRELLA, V. A.; GALLEGO, J.; DELFORGE, D. Y. M.; YAMAKAMI, W. J. Evaluation of the Hardness of the Stainless Steel ISO 5832-9 As a Function of The Aging Temperature Variation. Brazilian Congress of Engineering and Materials Science 17th, Foz do Iguaçu. Proceedings. Campinas: Unicamp, p. 4437-4448, 2006.

STAEHLE, R. W. Transient Stability of Passive Films in Aqueous Solutions. Corrosion Science, Minnesota, 2007.

TECMETAL. Characterization of Pipes of the Gas Discharge System (Pdeg). Technical Report, Macaé, 2004.

TELLES, P. C. S. Materials for process equipment. 6th. ed. Rio de Janeiro: Interciência, 2003. 